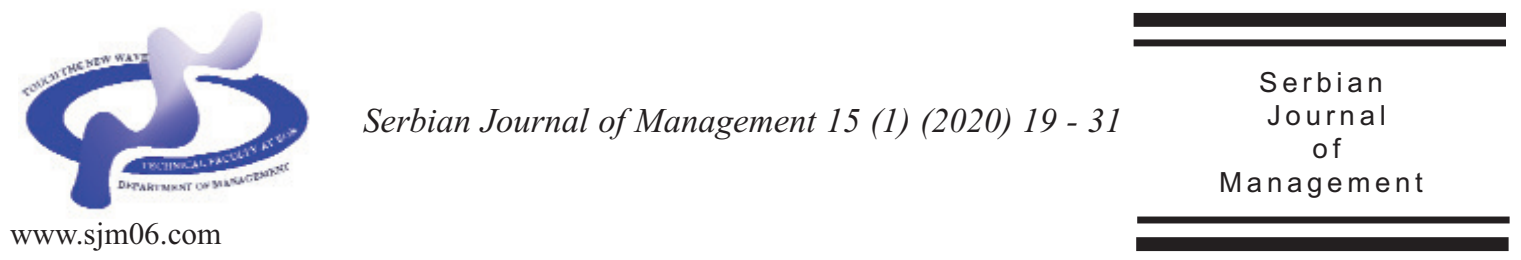

\title{
MATHEMATICAL MODEL AND METHOD OF COMPLEX ORGANIZATIONAL DIAGNOSTIC
}

\author{
Pavel Aleksandrovich Mikhnenko* \\ Moscow University for Industry and Finance "Synergy", \\ Department "General and Strategic Management" \\ Izmailovsky Val 2, Moscow, 105318, Russian Federation, \\ (Received 06 August 2018; accepted 18 February 2019)
}

\begin{abstract}
The paper is devoted to the complex diagnostic of structural and cultural properties of organizations. The study reveals the new diagnostic tool - the conjunctive matrix of the coordinationcultural profile of the organization. The concept of coordination mechanisms by Mintzberg was used for diagnostics of structural-managerial characteristics of organizations. To describe the organizational culture was used the model by Cameron and Quinn ("The Competing Values Framework"). For evaluation of explicitness of the coordination profile and the profile of organizational culture were used the coefficients of homogeneity. Depending on the ratio between the coefficients of homogeneity of the coordination profile and the cultural profile were substantiated four basic types of coordination-cultural profile: "Accurate Tuning", "Coordination Groundwork", "Culture Groundwork" and "Searching for a Basis". The study of twenty-two companies reveals that coordination-cultural profile "Accurate Tuning" provides the maximum economic efficiently of organizations.
\end{abstract}

Keywords: organizational diagnostic, coordination mechanisms, organizational culture, coordinationcultural profile, conjunctional matrix.

\section{INTRODUCTION}

Modern organizations are the complex systems which are characterized by various essences. Organization structure and organizational culture are the most important factors. Isolated managing of each of these factors gives unilateral results. Therefore interrelationships of structural and cultural properties of the organization require indepth study. According to H. Mintzberg, "The structure of an organization can be defined simply as the sum total of the ways in which its labor is divided into distinct

\footnotetext{
* Corresponding author: pmihnenko@synergy.ru
}

DOI: $10.5937 /$ sjm15-18513 
tasks and then its coordination is achieved among these tasks" (Mintzberg, 1983). Integrated analysis and regulation of coordination mechanisms and organizational culture can improve the efficiency of the organization's management.

For the first time the importance of organizational culture in the management was noted in 1938 by Ch. Barnard (Barnard, 1938). In the 1980s - 1990s, a lot of authors cover various aspects of organizational culture (Deal \& Kennedy, 1982; Pacanovski \& O'Donnell-Trujillo, 1982; Allaire \& Firsirotu, 1984; Barney, 1986; Cooke \& Lafferty, 1988; Cameron \& Quinn, 1999, etc.). Since the 1990s, authors have been discussing the problems of organizational culture at the context to organization's change, strategy, development, effectiveness and competitive advantage of organizations (Denison, 1990; Schein, 2004; Zheng et al., 2010; Hatch et al., 2015, etc.).

Nowadays many authors pay attention to the signs of interrelation and mutual conditioning of organizational culture and other organizational factors. Fey \& Denison (2003) examined the link between organizational culture and effectiveness for foreign-owned firms operating in Russia. Beginning with a model of organizational culture developed in the USA, the paper presents a multi-method analysis of culture and effectiveness in a transition economy. The authors argue that effectiveness in Russia relies more on adaptability and flexibility than in the USA. Zheng et al. (2010) examined the possible mediating role of knowledge management in the relationship between organizational culture, structure, strategy and organizational effectiveness. The study confirms the relevance of the new concepts and diagnostic procedures for the analysis of the interrelations and evaluating of organizational effectiveness. In the chapter "A Framework for Control and Culture" of monograph (Pfister, 2009) the author argues that not only the organizational culture influences the internal control, but the features of management affect the culture of an organization. The article is devoted to the approach to the development of organizational culture for increasing the effectiveness of internal control. Leonardi (2011) concluded that culture does not directly shape technological artifacts. Rather, a technology concept of organization activates culture. Technology concepts play a key role in selecting the set of cultural resources that will be used to develop technological artifacts. Janićijević (2013) explores the relationship between the structure and culture of an organization, assuming is that organizational structure and organizational culture impact each other, and that there is a causal relationship due to which the agreement of the two components of organization leads to better performance. Skarzhinskaia \& Tsurikov (2014) note that an important condition for ensuring the efficiency of joint actions in the team is the institution of a variety of horizontal ties and the rejection of rigid vertical structures, committed to the use of uniform norms and standards without the consideration of specific organizational situation. Heinickea et al. (2016) examined the relationship between the extent of a flexible organizational culture and the intense of using of the levers of control. The authors draw a conclusion that the more firms accentuate a flexible culture, the more they emphasize the use of beliefs controls and boundary control.

Thus, the study of the relationship and interaction of organizational culture and structural properties of organizations is an important scientific problem. 


\section{THE METHODS OF THE STUDY}

The main problem of this study is the development of the methodological and mathematical tools for research of mutual influence of basic structural-managerial and cultural properties of organizations. In this study, the concept of coordination mechanisms by Mintzberg was used for diagnostics of structural-managerial characteristics of organizations. According to Mintzberg, five coordination mechanisms seem to explain the fundamental ways in which organization coordinate their work: mutual adjustment, direct supervision, standardization of work processes, standardization of work outputs and standardization of worker skills. These should be considered the most basic elements of structure, the glue that holds organizations together (Mintzberg, 1983). In accordance with the thesis, a convenient tool for identifying managerial properties of organizations is the "Coordination Profile" the ratio (proportion) of the five coordination mechanisms.

The model by Cameron and Quinn ("The Competing Values Framework") will be used to describe the organizational culture. The model includes four types of culture: "Clan", "Hierarchy", "Market" and "Adhocracy" (Cameron \& Quinn, 1999).

The set of coordination mechanisms xi (the ways in which all units of organization coordinate their work) can be denoted as a column vector:

$$
\mathbf{X}=\left(x_{1}, x_{2}, \ldots, x_{i}, \ldots, x_{n}\right)^{\mathrm{T}},
$$

where $n$ is the number of the coordination mechanisms, $\mathrm{T}$ is the sign of the vector's transposition. For example, $x_{1}$ is the "Mutual adjustment"; $x_{2}$ is the "Direct supervision", etc.

The types of the organizational culture $y_{j}$ can be denoted as a row vector:

$$
\mathbf{Y}=\left(y_{1}, y_{2}, \ldots, y_{j}, \ldots, y_{m}\right)^{\mathrm{T}},
$$

where $m$ is the number of the organizational culture types'. For example, $y_{1}$ is the bureaucratic type; $y_{2}$ is the market type, etc.

Both of vectors (1) and (2) are the result of questionnaires of respondents (the employees and the managers of the organization). For questionnaire survey of the respondents was used questionnaire "The coordination profile assessment". Respondents chose one of the variants of the estimate: "Never", "Rarely", "Often", "Always" for each of the propositions of the assessment. For example: a) managers control only the final result of employees' work; b) informal conversation with colleagues is more useful than reading instruction; c) even short time absence of a head leads to disruptions in the work of the team; d) high qualification is not required for employee; etc.

The evaluation of coordination mechanisms $x_{i}$ by respondent $r$ is defined as

$$
x_{r}^{(i)}=\frac{\sum_{k=0}^{3} c_{k} a_{k}^{(i)}}{\sum_{i=1}^{n}\left(\sum_{k=0}^{3} c_{k} a_{k}^{(i)}\right)^{\prime}}
$$

where: $k$ is a number of the variant of the estimate: $k=0$, if the "Never" was chosen; $k=1$, if the "Rarely" was chosen, $k=2$, if the "Often" was chosen, $k=3$, if the "Always" was chosen; $c_{k}$ is a weighting coefficient of the variants of the estimate: $c_{0}=0, c_{1}=1$, $c_{2}=2, c_{3}=3 ; \quad$ is the sum of all of the estimates with the variant $k$ concerning of the coordination mechanism $x_{i}$.

Suppose the coordination mechanism 
"Mutual adjustment" was estimated. Respondent $r_{1}$ chose the option "Never" for the statement 1, the option "Rarely" for the statements 3 and 5, the option "Often" for the statements 2 and 4 and 8 , the option "Always" for the statements 6 and 7. In this case $\sum_{k=0}^{3} c_{k} a_{k}^{(1)}=0 \cdot 1+1 \cdot 2+2 \cdot 3+3 \cdot 2=14$.

Suppose the total sum $\sum_{i=1}^{n}\left(\sum_{k=0}^{3} c_{k} a_{k}^{(i)}\right)=52$, then $x_{1}^{(1)}=\frac{14}{52} \cong 0.269$.

The final evaluation $x i$ is calculated as the average by the number of all respondents $\mathrm{R}$ :

$$
x_{i}=\frac{1}{R} \sum_{r=1}^{R} x_{r}^{(i)}, \sum_{i=1}^{n} x_{i}=1 .
$$

Figure 1 illustrates the combination of the coordination mechanisms - the coordination profile of organization.

"The Organizational Culture Assessment Instrument" (OCAI) by K. Cameron and R. Quinn was used for empirical estimation of the profile of organizational culture (Cameron \& Quinn, 1999). The OCAI consists of six content dimensions (Cameron \& Quinn, 1999): 1) the dominant characteristics of the organization, or what the overall organization is like; 2) the leadership style and approach that permeate the organization; 3) the management of employees or the style that characterizes how employees are treated and what the working environment is like; 4) the organizational glue or bonding mechanisms that hold the organization together; 5) the strategic emphases that define what areas of emphasis drive the organization's strategy; 6) the criteria for success that determine how victory is defined and what gets rewarded and celebrated.

Every dimension has four alternatives A, B, C and D indicating the four types of organizational culture: $y_{1}-$ Clan, $y_{2}-$ Hierarchy, $y_{3}-$ Market and $y_{4}-$ Adhocracy. The authors suggest dividing 100 points (percent) among these four alternatives, depending on the extent to which each alternative "is similar to" the organization.

The evaluation of culture's type $y_{j}$ by respondent $r$ is defined as

$$
y_{r}^{(j)}=\frac{0.01}{6} \sum_{d=1}^{6} b_{j}^{(d)}, \sum_{j=1}^{m} b_{j}^{(d)}=100 \%
$$

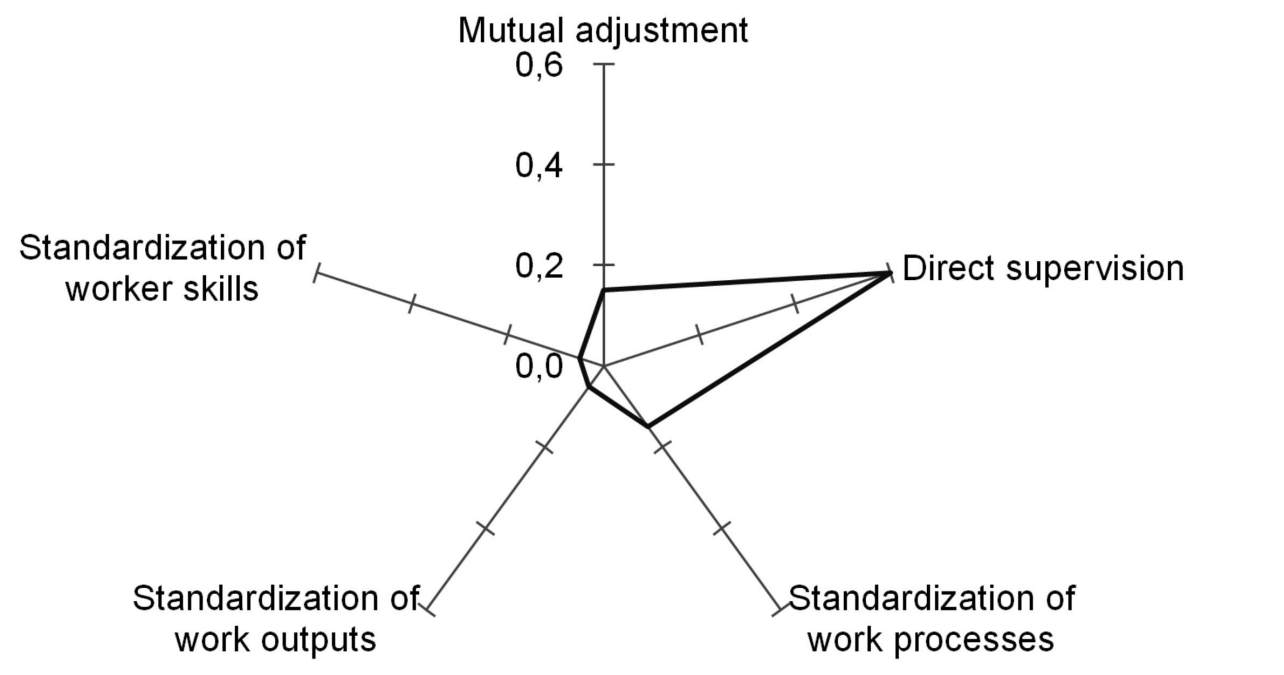

Figure l. The coordination profile "Arrow", $n=5$ (the example) 
where the number 6 signifies the six content dimensions of culture by Cameron and Quinne; $d$ is a number of the dimension; $b_{j}(d)$ is an evaluation of the cultural type $j$ at the dimension $d$; the coefficient 0.01 converses of the percentage to the decimal fractional number.

The final evaluations $y_{j}$ calculated as the average by the number of all respondents R:

$$
y_{j}=\frac{1}{R} \sum_{r=1}^{R} y_{r}^{(j)}, \sum_{j=1}^{m} y_{j}=1 .
$$

The Figure 2 illustrates the profile of organizational culture.

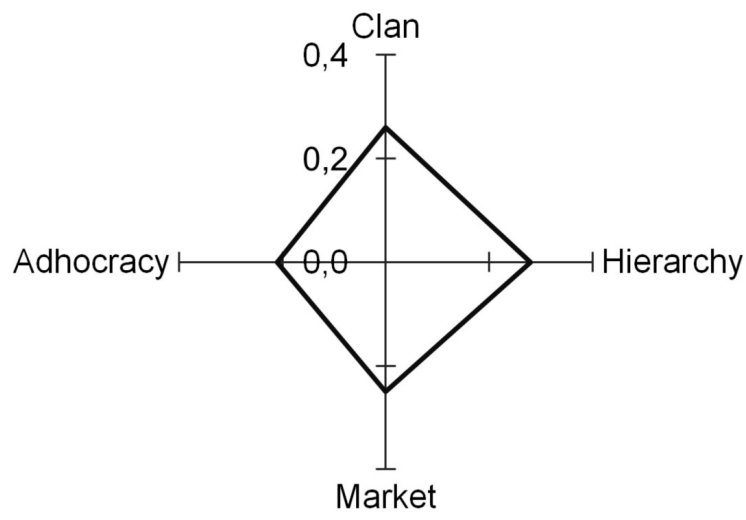

Figure 2. The profile of organizational culture "Spot", $m=4$ (the example)

For evaluation of explicitness of the coordination profile was used the coefficient of homogeneity:

$$
h_{x}=\max _{i} x_{i}-\frac{1-\max _{i} x_{i}}{n-1} .
$$

The coefficient of homogeneity $h_{x}$ takes the value 1 when one of the evaluations $x_{i}$ is equal to 1 and other evaluations are equal to 0 ; and $h_{x}=0$ when $x_{i}=1 / n, \mathrm{i}=1, n$. Similarly coefficient of homogeneity of the cultural profile $h_{y}$ is such that:

$$
h_{y}=\max _{j} y_{j}-\frac{1-\max _{j} y_{j}}{m-1} .
$$

The coefficient of homogeneity $h_{y}$ takes the value 1 when one of the evaluations is equal to 1 and other evaluations are equal to 0 ; and $h_{y}=0$, when $y_{j}=1 / m, j=1, m$. The coefficient of homogeneity for the coordination profile (Figure 1) $h_{x}=0.50$; the coefficient of homogeneity for the culture profile (Figure 2) $h_{y}=0.04$. Therefore, explicitness of the coordination profile is much more then explicitness of the cultural profile. These profiles indicate that management of the organization prefers to use the coordination mechanism $x_{2}$ more often than others, while the organizational culture does not have a specific singlevalued type.

The isolated study of the coordination profile and the profile of cultural does not give answers to important questions: How the organizational culture was evolved to this form? How the cultural change will affect the effectiveness of the coordination mechanisms? How the changes of coordination mechanisms will affect the organizational culture? Synchronous control of both the profiles provides answers to these questions.

The multiplication of $\mathbf{X}$ and $\mathbf{Y}$ is equal to the conjunctive matrix (CM), which is a mathematical model of the coordinationcultural profile (CCP) of the organization:

$$
\mathbf{X} \times \mathbf{Y}=\left(x_{i} y_{j}\right)_{n \times m}=\Lambda_{n \times m}=\left(\lambda_{i j}\right)_{n \times m}, \sum_{i j} \lambda_{i j}=1
$$

The element $\lambda_{i j}=x_{i} y_{j}$ of the CM corresponds to logical conjunction $\lambda_{i j} \rightarrow x_{i} \cap y_{j}$. The matrix, corresponding to the profiles shown in Figure 1 and Figure 2, has the form (Table 1): 
Table 1. The CM of CCP

\begin{tabular}{lcccc}
\hline \multirow{2}{*}{ Coordination mechanisms } & \multicolumn{4}{c}{ Types of organizational culture } \\
\cline { 2 - 5 } & Clan & Hierarchy & Market & Adhocracy \\
\hline Mutual adjustment & 0,039 & 0,042 & 0,038 & 0,032 \\
Direct supervision & 0,156 & 0,168 & 0,150 & 0,126 \\
Standardization of work processes & 0,039 & 0,042 & 0,038 & 0,032 \\
Standardization of work outputs & 0,013 & 0,014 & 0,013 & 0,011 \\
Standardization of worker skills & 0,013 & 0,014 & 0,013 & 0,011 \\
\hline
\end{tabular}

The CM obviously indicates that the basis of the CCP of the organization consists of the conjunctions $\lambda_{21}, \lambda_{22}, \lambda_{23}$ and $\lambda_{24}$ (they are marked by the dark color of the matrix cells). The values of the cells $\lambda_{21}, \lambda_{22}, \lambda_{23}$ and $\lambda_{24}$ matches the inequality $\lambda_{i j} \geq \lambda_{\max }-\sigma_{\lambda}$, where $\sigma_{\lambda}-$ standard deviation. Obviously, the conjunction $\lambda_{22}=\lambda_{\max }=0.168$ is the most representative one. The study of the essence of conjunctions $\lambda_{21}, \lambda_{22}$ and $\lambda_{23}$ allows us to understand the coordination-culturing features of the organization. Every conjunction indicates the bilateral ratio between the coordination mechanism and the type of culture. For instance, the conjunction $\lambda_{22}$ reveals that hierarchical culture $y_{2}$ was formed under the influence of the regular using by managers the coordination mechanism $x_{2}-$ "Direct supervision". It can be assumed that the habit to apply the direct supervision was encouraged and inspired by the longstanding hierarchical traditions and rules. The conjunction $\lambda_{54}$ points to the interrelation $x_{5}$ - "Standardization of worker skills" and $y_{4}-$ "Adhocracy", but the intensity of the relationship is not high $\lambda_{54}=$ 0.011 (Table 1).

The variability of the CCP of organization depends on the variety of coordination mechanisms and the diversity of organizational culture. The coefficient of variability $\eta_{x}$ allows estimating the degree of coordination mechanisms' influence to the CM $\eta_{x}=\frac{\delta_{x}}{\sigma_{\lambda}^{2}}, 0 \leq \eta_{x} \leq 1$,

where $\delta_{x}-$ intergroup dispersion, characterizing the systematic variation $\lambda_{i j}$ due to the grouping of coordination mechanisms:

$$
\delta_{x}=\frac{1}{m} \sum_{j=1}^{m}\left(\lambda_{j}^{*}-\lambda\right)^{2},
$$

where $\lambda_{j}^{*}=\frac{1}{n} \sum_{i=1}^{n} \lambda_{i j}$

- separate average by type of coordination mechanisms, $\lambda=\frac{1}{n m} \sum_{i=1}^{n} \sum_{j=1}^{m} \lambda_{i j}$.

Analogically defined the coefficient of variability $\eta_{y}$ for organizational culture:

$\eta_{y}=\frac{\delta_{y}}{\sigma_{\lambda}^{2}}, \delta_{y}=\frac{1}{n} \sum_{i=1}^{n}\left(\lambda_{i}^{*}-\lambda\right)^{2}, \lambda_{i}^{*}=\frac{1}{m} \sum_{j=1}^{m} \lambda_{i j}$

In case of the CM (Table 1): $\eta_{x}=0.01$ (i.e. $1.0 \%$ ) and $y_{y}=0.98$ (i.e. $98 \%$ ). Thus, the variability of the CCP depends mainly on the variability of organizational culture. However, since the main conjunctions are $\lambda_{21}, \lambda_{22}$ and $\lambda_{23}$, the most interesting is the relationship between the types of culture $y_{1}$, $y_{2}$ and $y_{3}$ with the coordination mechanism $x_{2}$.

Table 2 illustrates the CM of the CCP of the small company "Alfa"1 engaging the repair of living quarters, which was tested in 2015.

${ }^{1}$ The name was changed at the request of the company's owner. 
The company was established in 2013. In the number of the company's staff was sixteen employees, and the main conjunctions were: "Mutual adjustment and Clan" and "Mutual adjustment and Market" (Table 2). By 2017, the number of customer orders was doubled, and the number of staff amounted to 43 employees. As a result, the $\mathrm{CM}$ was changed and the main conjunction has become "Standardization of work processes and Market" (Table 3).

In 2016 the variability of the CCP was: $\mathrm{y}_{x}=0.382$ and $\mathrm{y}_{y}=0.567$; in 2017 the variability of coordination profile was increased to $y_{x}=0.723$ and the variability of culture was reduced to $\eta_{y}=0.174$. It means that the market's changes induced the company to change the CCP to strengthen "Market" culture and standardization of work processes. This CCP helps to increase the productivity in the direction of market goals. Perhaps in the future, the CCP will change again, for example, in the direction of adhocracy culture and the standardization of skills for conversion the company to a project-matrix structure.
The aggregate coefficient of variability indicates the influence the total variability of coordination profile and profile of culture to the CCP of organization $(\mathrm{y} \leq 1)$ :

$$
\eta=\eta_{x}+\eta_{y}=\frac{\delta_{x}+\delta_{y}}{\sigma_{\lambda}^{2}}
$$

If $\eta=1$ then $\eta=\delta_{x}+\delta_{\mathrm{y}}=\sigma_{\lambda}^{2}$, i.e. the dispersion of the $\mathrm{CM} \sigma_{\lambda}^{2}$ depends only on the sum of the intergroup dispersions, characterizing the systematic variation $\lambda_{\mathrm{ij}}$ due to the grouping of coordination mechanisms and types of organizational culture.

The aggregate coefficient of variability for 2015 year $\eta_{2015}=0.382+0.567=0.949$ and the aggregate coefficient of variability for 2017 year $\eta_{2017}=0.723+0.174=0.897$. Thus the overall variability of the CCP of the company "Alfa" decreased by $5.5 \%$ within two years.

What types of CCP can be? Theoretically, depending on the ratio between the coefficients of homogeneity of the coordination profile $h_{x}$ and the cultural profile $h_{y}$ there are four basic types of CCP (Figure 3 ).

Table 2. The CM of CCP of the firm (2015 year)

\begin{tabular}{lcccc}
\hline \multirow{2}{*}{ Coordination mechanisms } & \multicolumn{4}{c}{ Types of organizational culture } \\
\cline { 2 - 5 } & Clan & Hierarchy & Market & Adhocracy \\
\hline Mutual adjustment & 0,106 & 0,080 & 0,093 & 0,042 \\
Direct supervision & 0,079 & 0,060 & 0,070 & 0,031 \\
Standardization of work processes & 0,036 & 0,028 & 0,032 & 0,014 \\
Standardization of work outputs & 0,056 & 0,043 & 0,049 & 0,022 \\
Standardization of worker skills & 0,053 & 0,040 & 0,046 & 0,021 \\
\hline
\end{tabular}

Table 3. The CM of CCP of the firm (2017 year)

\begin{tabular}{lcccc}
\hline \multirow{2}{*}{ Coordination mechanisms } & \multicolumn{4}{c}{ Types of organizational culture } \\
\cline { 2 - 5 } & Clan & Hierarchy & Market & Adhocracy \\
\hline Mutual adjustment & 0,008 & 0,019 & 0,046 & 0,007 \\
Direct supervision & 0,019 & 0,046 & 0,108 & 0,017 \\
Standardization of work processes & 0,032 & 0,077 & 0,182 & 0,029 \\
Standardization of work outputs & 0,020 & 0,048 & 0,114 & 0,018 \\
Standardization of worker skills & 0,021 & 0,050 & 0,120 & 0,019 \\
\hline
\end{tabular}




\begin{tabular}{|c|c|c|c|}
\hline \multirow{3}{*}{$\begin{array}{l}\text { Coefficients of } \\
\text { homogeneity of the } \\
\text { coordination } \\
\text { profile }\end{array}$} & High & $\begin{array}{l}\text { Coordination Groundwork } \\
\text { (Explicit coordination } \\
\text { / Implicit culture) }\end{array}$ & $\begin{array}{l}\text { Accurate Tuning } \\
\text { (Explicit coordination } \\
\text { / Explicit culture) }\end{array}$ \\
\hline & Low & $\begin{array}{l}\text { Searching for a Basis } \\
\text { (Implicit coordination } \\
\text { / Implicit culture) }\end{array}$ & $\begin{array}{l}\text { Culture Groundwork } \\
\text { (Implicit coordination } \\
\text { / Explicit culture) }\end{array}$ \\
\hline & & Low & High \\
\hline
\end{tabular}

Figure 3. The typology of CCP

The type "Accurate Tuning" fits the organization archetype, which is based on mainly one of the coordination mechanisms and one of the types of organizational culture, for example "standardization of work processes" and "hierarchy". The "Culture Groundwork" is characterized the organization archetype with a clear and unambiguous type of organizational culture and a wide spectrum of coordination mechanisms. Over time, management can choice the corresponding dominant coordination mechanism, and the organization will acquire the features of the "Accurate Tuning". The "Coordination Groundwork" is the organization archetype basing on a wide spectrum of organizational culture's types and unambiguous coordination mechanism. Figures 1 and 2 illustrate this type of CCP. The "Searching for a basis" is the organization archetype, in which determined neither coordination mechanism, nor organizational culture's type. "Searching for a basis" is typical for organizations in which, due to various circumstances, strong culture with a pronounced type are not formed, and there is no management view of the need to consider one of the coordination mechanisms as the main.

\section{EMPIRICAL RESULTS}

In 2017 was conducted the survey of twenty-two Russian firms of small and medium-sized businesses. The research involved firms engaged in construction business, repair and reconstruction of residential and office premises. The age of the firms was in the range from 2 to 28 years (Figure 4), the size (amount of employees) from 12 to 120 people (Figure 5).

As a result was obtained two diagrams - the maps of the CCP types (Figures 6 and 7). Figure 6 reveals that there is no an unambiguous relation between the types of $\mathrm{CCP}$ and average size of companies. But the maximal average size (66 employees) matches to the "Accurate Tuning" with maximal standard deviation (48.3) (Table 4). Figure 7 and Table 4 reveal that the maximal average age (14.6 years) matches to "Accurate Tuning" too, however, high level of standard deviation (11.6) do not allow to consider this conclusion as accurate. The minimal average age (5.5 years) with a small value of standard deviation (1.7) matches to the "Searching for a Basis".

Figures 6 and 7 reveal that the "Accurate Tuning" can correspond to both the big (aged) and the small (young) firms. The "Searching for a Basis" generally characterizes young firms. 


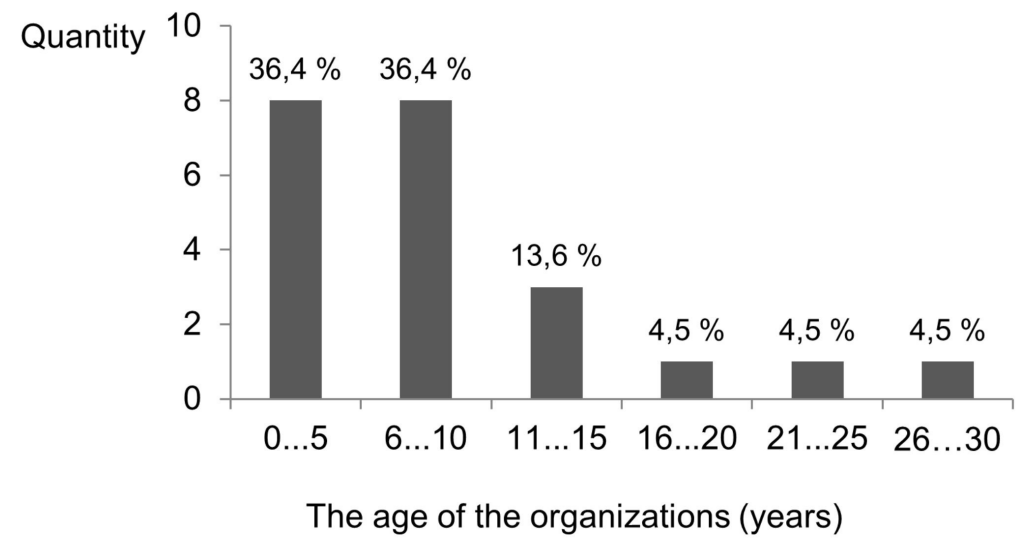

Figure 4. The histogram of the organizations'age

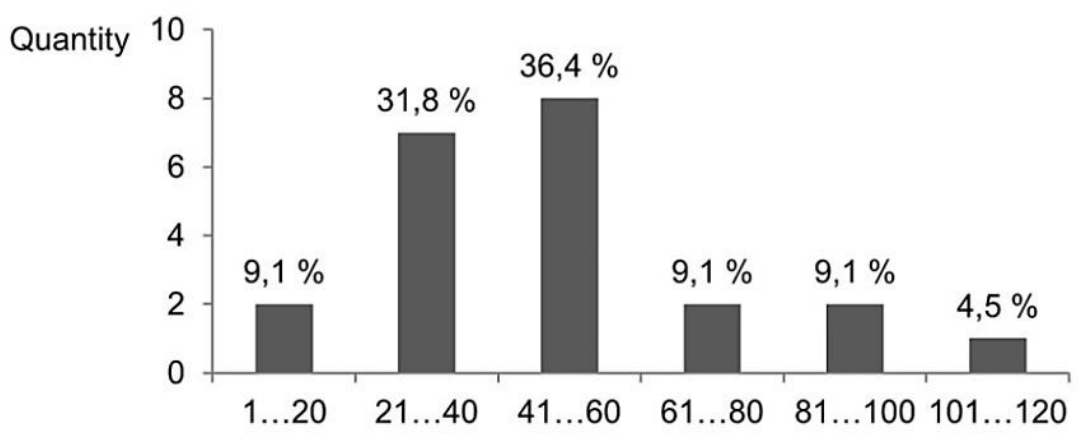

The size of the organizations (employees)

Figure 5. The histogram of the organizations' size

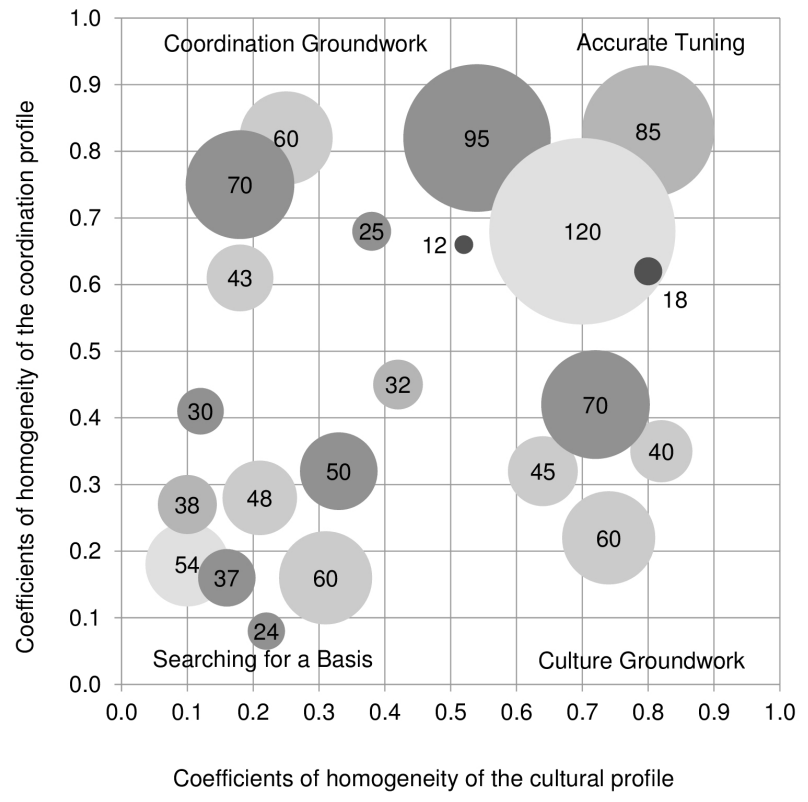

Figure 6. The map of the CCP types (the diameter of the bubble matches to the number of staff) 


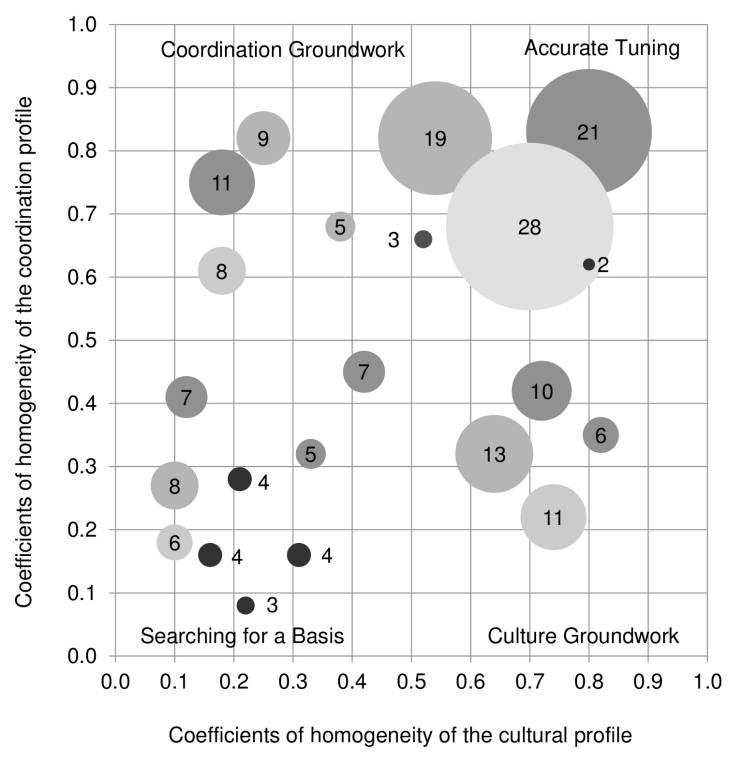

Figure 7. The map of the CCP types (the diameter of the bubble matches to the age of the organization, years)

Table 4. The statistic characteristics of CCP types

\begin{tabular}{lccccc}
\hline & \multicolumn{5}{c}{ Characteristics of organizations } \\
\cline { 2 - 6 } Coordination-cultural profiles & Quantity & $\begin{array}{c}\text { Average } \\
\text { size }\end{array}$ & $\begin{array}{c}\text { Standard } \\
\text { deviation }\end{array}$ & $\begin{array}{c}\text { Average } \\
\text { age }\end{array}$ & $\begin{array}{c}\text { Standard } \\
\text { deviation }\end{array}$ \\
\hline Accurate Tuning & 5 & 66,0 & 48,3 & 14,6 & 11,6 \\
Culture Groundwork & 4 & 53,8 & 13,8 & 10,0 & 2,9 \\
Coordination Groundwork & 4 & 49,5 & 19,8 & 8,3 & 2,5 \\
Searching for a Basis & 9 & 41,4 & 12,1 & 5,5 & 1,7 \\
\hline Total/Average & 22 & 52,7 & 23,5 & 9,6 & 4,7 \\
\hline
\end{tabular}

The owners of most firms refused to provide their fool financial statements. Nevertheless, 19 out of 22 companies agreed to give the conditional estimates of their economic efficiency for 2017 - return on sales (ROS, \%). The Figure 8 indicates the dependence of average coefficient of homogeneity $(h)$ on ROS, where $h=0.5\left(h_{x}+\right.$ $\left.h_{y}\right)$.

The increase in homogeneity entails the growth in ROS (the reliability exponential approximation $\left.\mathrm{R}^{2}=0.4941\right)$. The "Accurate Tuning" firms (white rhomb in Figure 8) have most high estimates of economic efficiency (average ROS is $18.80 \%$ ). These results allow concluding about the high economic efficiency of the "Accurate Tuning" regardless of the age and size of the company. The "Cultural Groundwork" firms (white square in Figure 8) have high value of ROS too (average ROS is $16.35 \%$ ). The "Coordination Groundwork" firms (black circle in Figure 8) have medium value of ROS (average ROS is $15.67 \%$ ), and the "Searching for a Basis" firms (black rhomb in Figure 8) have lowest value of ROS (average ROS is $12.69 \%$ ). The combinations of the culture and the dominant coordination mechanism in the "Accurate Tuning" are different for different types of the firms. The conjunction "Standardization of work 


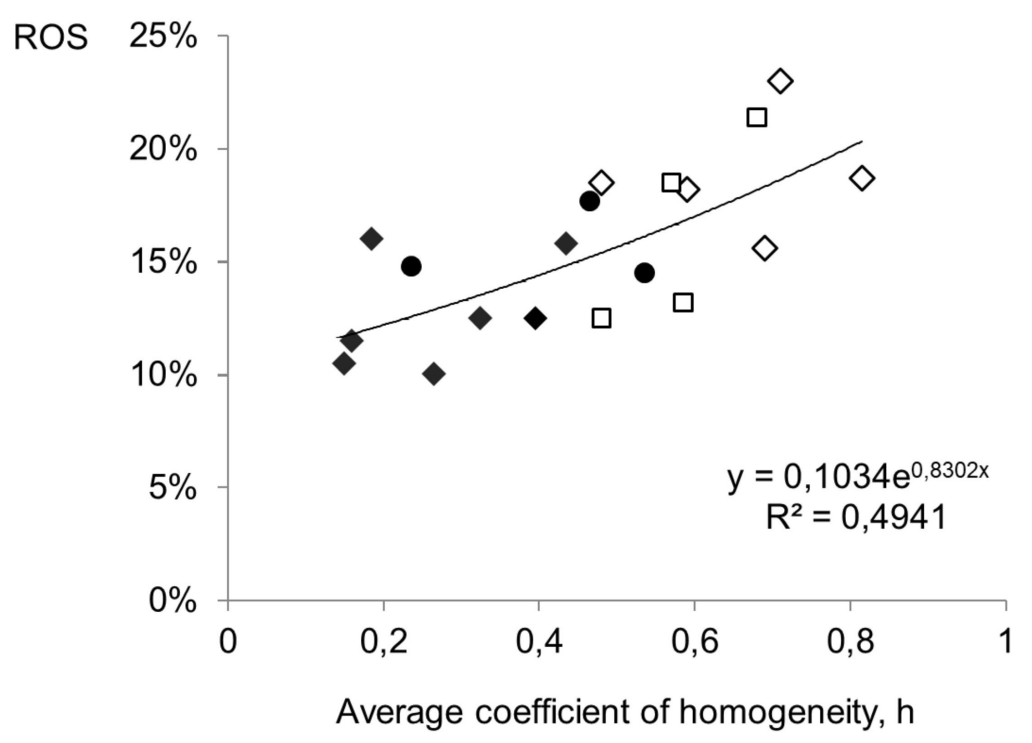

Figure 8. Return on sales (ROS) as a function of average coefficient of homogeneity (h)

processes and Hierarchy" is the base of "Accurate Tuning" for three firms (the numbers of staff 120, 95 and 85 employees). However, the conjunction "Mutual adjustment and Adhocracy" is the base of "Accurate Tuning" for two firms (the numbers of staff 12 and 18 employees).

\section{DISCUSSIONS AND CONCLUSIONS}

Organizational culture and coordination mechanisms are the important components of organization's internal environment. Mintzberg examines the influence of coordination mechanisms on organizational archetypes, without setting a task to identify their direct influence on the organization's culture (Mintzberg, 1983). In the literature, the mutual impact of organizational culture and other organizational factors are widely discussed. A lot of studies confirm that organizational culture influences the control, structure and strategy, and the methods of control; structure and strategy for its part affect the culture (Zheng et al., 2010; Pfister, 2009). Leonardi (2011) concludes that technology concept of organization activates its culture. There is a reason to believe that coordination profile of organization is one of important parts of its technology pattern. So coordination mechanisms and coordination profile can be considered as key aspects of organizational culture. Janićijević (2013) reveals the mutual interdependence particular types of organizational culture and particular types of organizational structure.

This study in some sense corresponds to papers by Heinickea et al. (2016), Janićijević (2013), Zheng et al. (2010), Skarzhinskaia \& Tsurikov (2014) and other authors studying the problem of relationship between culture and another organization factors. Unlike other studies on this topic, this study aims at investigating the organizational culture and the coordination profile as a continuum "coordination-cultural profile", the properties of which significantly affect the effectiveness of the organization's management and its economic success. The 
results suggest that synchronous control of both components of organization's internal environment is the key to the organizational effectiveness.

The second difference of the study lies in the construction of a mathematical model of the continuum - the conjunctive matrix. Conjunctive matrix as a mathematical model of coordination-cultural profile is a new practical instrument for organizational analysis. The scientific value of this study consists of a new research methodology organization's internal environment. The main practical merit of the research is to identify the type of coordination-cultural profile "Accurate Tuning" which provides the increase of management efficiency. This profile is a combination of an explicit type of culture and an explicit coordination profile (with dominant coordination mechanism). At that, the combinations can be different. The important task of management is formation effective combination of culture and main coordination mechanism, which correspond to the specifics of the economic activities of the organization.

At the first stage of the study are used only models by Minzberg (coordination mechanisms and organization archetypes) and Cameron and Quinn (organizational culture). For further research is planned to develop author's models more suitable for integrated analysis of coordination-cultural characteristics. There is a reason to suppose that subsequent research will identify the relationship between coordination-cultural profile and specific economic activities (types of industries) of organizations. Another limitation of this study is subjective character of interpretation cultural and coordinating profiles due to personal opinions of respondents (employees and managers). This problem will be resolved by using perfect methods of questionnaire survey and mathematical statistics.

\section{МАТЕМАТИЧКИ МОДЕЛ И МЕТОДА СЛОЖЕНЕ ОРГАНИЗАЦИОНЕ ДИЈАГНОСТИКЕ}

\section{Pavel A. Mikhnenko}

\section{Извод}

Рад је посвећен сложеној дијагностици структуралних и културних својстава организација. Студија открива нови дијагностички алат - коњуктивну матрицу координационо-културног профила организације. Концепт механизама координације Минтзберг је коришћен за дијагностику структурно-управљачких карактеристика организација. За опис организационе културе, коришћен је модел “Саmeron and Quinn” (тзв. „Оквир конкурентских вредности“). За процену експлицитности профила координације и профила организационе културе, коришћени су коефицијенти хомогености. У зависности од односа коефицијената хомогености профила координације и културног профила, утемељене су четири основне врсте координационокултурног профила: „Прецизно подешавање“, „Координациони темељни рад“, „Културни основни рад“ и „Тражење основа“. Студија двадесет и две компаније открива да координационокултурни профил „Прецизно подешавање“ пружа максималну економску ефикасност организација.

Кључне речи: организациона дијагностика, механизми координације, организациона култура, координационо-културни профил, коњунктивна матрица. 


\section{References}

Allaire, Y., \& Firsirotu, M. (1984). Theories of Organizational Culture. Organization Studies, 5, 193-226.

Barnard, C.I. (1938). The Functions of the Executive. Boston, USA: Harvard University Press.

Barney, J.B. (1986). Organizational Culture: Can it be a Source of Sustained Competitive Advantage? Academy of Management Review, 11, 656-665.

Cameron, K.S. \& Quinn, R.E. (1999). Diagnosing and Changing Organizational Culture. Based on The Competing Values Framework. San Francisco, CA, USA: Addison-Wesley Publishing Company, Inc.

Cooke, R.A., \& Lafferty J.C. (1988). Organizational Culture Inventory. Group \& Organization Management, 13 (3), 245-273.

Deal, T.E., \& Kennedy, A.A. (1982). Corporate Cultures: The Rites and Rituals of Corporate Life, Reading, MA: AddisonWesley Publishing Co.

Denison, D.R. (1990). Corporate Culture and Organizational Effectiveness, New York: Wiley.

Fey, C.F., \& Denison D.R. (2003). Organizational Culture and Effectiveness: Can American Theory Be Applied in Russia? The William Davidson Institute at the University of Michigan Business School, William Davidson Institute Working Paper, 598, July, 57-66.

Hatch, M.J., Schultz M., \& Skov A. (2015). Organizational Identity and Culture in the Context of Managed Change: Transformation in the Carlsberg Group, 2009-2013. Academy of Management Discoveries, 1, 58-90.

Heinickea, A., Guenthera, T.W., \& Widenerb, S.K. (2016). An examination of the relationship between the extent of a flexible culture and the levers of control system: The key role of beliefs control. Management Accounting Research, 33, 25 41.

Janićijević, N. (2013). The mutual impact of organizational culture and structure. Economic Annals, LVIII (198), 35-60.

Leonardi, P.M. (2011) Innovation Blindness: Culture, Frames and CrossBoundary Problem Construction in the Development of New Technology Concepts. Organization Science, 22 (2), 347-369.

Mintzberg, H. (1983) Structure in Fives: Designing Effective Organizations. New York, USA: Prentice-Hall.

Pacanovski, M., \& O’Donnell-Trujillo N. (1982). Communication and Organization Culture. The Western Journal of Speech Communication, 46, 115-130.

Pfister, J.A. (2009). Managing Organizational Culture for Effective Internal Control. From Practice to Theory (Contributions to Management Science). Heidelberg, DE: Springer Phisica-Verlag.

Schein, E.H. (2004). Organizational culture and leadership. 3rd ed. San Francisco, CA, USA: Jossey-Bass.

Skarzhinskaia, E.M., \& Tsurikov, V.I. (2014). On the effectiveness of collective action. Russian Management Journal, 12 (3), 87-106 (in Russian).

Zheng, W., Yang, B., \& McLean, G.N. (2010). Linking organizational culture, structure, strategy, and organizational effectiveness: Mediating role of knowledge management. Journal of Business Research, $63,763-771$. 